\title{
Tahapan Pengambilan Keputusan dalan Pemberian Asuhan Keperawatan
}

\author{
Adisty Olyvia Hutagalung
}

adistyhutagalung@gmail.com

\section{Latar Belakang}

Perawat juga sebagai seorang praktisi yang berpendidikan diharapkan mempunyai kemampuan intelektual untuk menggunakan pemikiran rasional dan refektif saat perawat mempertimbangkan pengamatan dan informasi tentang kondisi masing-masing pasien. Sepanjang komponen dari proses keperawatan, perawat menggunakan sikap dan kemampuan berfikir kritis untuk menentukan relevansi, makna dan iterrelasi data pasien serta untuk memilih dan menetapkan asuhan keperawatan yang sesuai (Cristensen \& Kenney, 2009). Berfikir kritis penting dilakukan sebelum mengambil keputusan dalam asuhan keperawatan karena merupakan salah satu metode ilmiah dalam menyelesaikan masalah klien. Kemampuan perawat mengidentifikasi masalah klien dan memilih solusi intervensi yang tepat tidak lepas dari kemampuan perawat berfikir kritis untuk mengali berbagai alasan berdasarkan evidence base dari setiap problem dan solusi yang teridentifikasi (Potter\& Perry, 2010).

Perawat merupakan tenaga profesional yang bertanggung jawab dalam memberikan proses keperawatan kepada klien. Berdasarkan hal tersebut perawat harus mampu mengambil keputusan klinis sebagai upaya membantu pasien dalam memecahkan masalah dan menemukan jalan keluar dari setiap masalah keperawatan yang dialami pasien. Perawat selalu dihadapkan dengan berbagai masalah klinis dalam memberikan perawatan terhadap pasien. Perawat yang profesional tentu saja akan mampu mengambil keputusan klinik agar masalah pasien dapat diatasi dengan cepat dan tepat. Pengambilan keputusan klinik berhubungan dengan beberapa faktor diantaranya adalah: usia, pendidikan sertifikat yang dimiliki perawat, lamanya kerja di unit dan unit tempat perawat bekerja. Kurang terampilnya perawat dalam melakukan pengambilan keputusan klinik tentu saja akan berdampak kepada kualitas pelayanan keperawatan yang diberikan.

Kemampuan membuat keputusan klinik oleh perawat merupakan inti dari praktik keperawatan. Asuhan keperawatan yang diberikan oleh perawat kepada pasien menuntut perawat untuk mengambil keputusan dalam setiap tindakan dan proses keperawatan. Perawat yang tidak terampil dalam mengambil keputusan klinik tentunya akan merugikan pasien 
sebagai penerima perawatan. Oleh karena itu, tujuan penelitian ini untuk mengetahui gambaran tahapan pengambilan keputusan dalam pemberian asuhan keperawatan.

\section{Metode}

Metode yang digunakan adalah literature review. Kajian literature meninjau literatur ilmiah tentang sebuah topik dan secara kritis menganalisis, mengevaluasi, dan mensintesis temuan penelitian, teori, dan praktik. Pencarian artikel penelitian menggunakan tesis, disertasi, skripsi, jurnal dan ebook dengan menggunakan kata kunci yaitu tahapan, pengambilan keputusan, asuhan keperawatan, perawat. Kriteria inklusi yaitu artikel full text yang berbahasa Inggris atau berbahasa Indonesia dipublikasikan dengan tahun paling tua 2012. Jumlah keseluruhan artikel yang didapatkan dilakukan penyaringan sesuai dengan kriteria inklusi sehingga hasil akhir ditemukan 10 artikel yang di review.

\section{Hasil}

Pengambilan keputusan (Decision making). Pengambilan keputusan adalah suatu hasil atau keluaran dari proses mental atau kognitif yang membawa pada pemilihan di antara beberapa alternatif yang tersedia yang dilakukan oleh seorang pembuat keputusan. Keputusan dibuat untuk mencapai tujuan melalui pelaksanaan/ implementasi dari pilihan keputusan yang diambil.

Dalam Jurnal Keperawatan (2013) Pemecahan masalah secara rasional untuk mengatasi segala sesuatu yang dapat menimbulkan perasaan tidak nyaman, tidak menyenangkan baik bagi diri sendiri maupun orang lain secara langsung maupun tidak langsung. Pengambilan keputusan adalah suatu proses pemikiran dalam rangkaian penyelsaian / pemecahan suatu masalah untuk memperoleh hasil.

Kreatifitas adalah merupakan kemampuan seseorang bergantung pada data/ informasi yang tersedia, menemukan kemungkinan jawaban terhadap suatu masalah dengan kuantitas,ketepat gunaan dan keragaman jawaban. Setiap permasalahan perlu penyelesaian dengan berfikir kritis yang menciptakan ide atau kreatifitas. Oleh karena itu setiap pengambilan keputusan dalam pemecahan masalah adalah keputusan yang tepat untuk menyelesaiakan setiap masalah yang timbul (Robbert, 2001).

Dalam e-Jurnal Pustaka Kesehatan (2017) Proses dasar pembuatan keputusan mencakup identifikasi dan diagnosa masalahyaitu mengenali (mengidentifikasi) dan menentukan (mendefinisikan) masalah, pengumpulan data yang relevan yaitu menentukan 
data-data apa yang akan dibutuhkan untuk membuat keputusan yang tepat dan kemudian mendapatkan informasi tersebut, pengembangan alternatif yaitu pencarian solusi potensial untuk masalah tersebut guna memperoleh informasi sehingga dapat dikembangkan menjadi alternatif yang mungkin, evaluasi alternatif yaitu mengevaluasi untuk menilai efektivitas setiap alternatif dengan melihat dampak positif dan dampak negatifnya, pemilihan alternatif terbaik yaitu memecahkan masalah guna mencapai tujuan yang direncanakan sebelumnya, implementasi keputusan yaitu menguji keputusan dengan melihat perilaku orang yang dipengaruhi keputusan itu serta pengendalian dan evaluasi yaitu Perubahan, jika perlu dibuat solusi yang dipilih pada saat implementasi, atau jika tujuan awal dianggap tidak tercapai.

Dalam Manajemen dan Kepemimpinan dalam praktek Keperawatan (2016) Proses Pengambilan Keputusan Proses keperawatan

Pengumpulan data : Identifikasi masalah, Perencanaan terdiri dari Penentuan tujuan, Identifikasi solusi, Implementasi, Evaluasi dan Revisi Proses.

Dalam Konsep Dasar Keperawatan (2016) berikut panduan dalam proses untuk pengambilan keputusan etis yaitu menunjukkan maksud baik, mengidentifikasi semua orang penting, mengumpulkan informasi yang relevan, mengidentifikasi prinsip etis yang penting, mengusulkan tindakan informatif, dan melakukan tindakan

\section{Pembahasan}

Perawat memiliki kewajiban etis untuk mendukung, meningkatkan dan membantu pengambilan keputusan klien, untuk mendukung hak klien pada informed consent untuk memberikan informasi mengenai resiko yang akan datang ketika tindakan itu diberikan kepadanya dan untuk mengikuti jalan yang diambil klien. Pertimbangan etis yang meliputi tantangan dalam masalah dan dilema etis dapat diarahkan dengan metode proses asuhan keperawatan. Hal terbaik sebelum diambil suatu keputusan sebaiknya didiskusikan terlebih dahulu antara klien dengan perawat atau petugas kesehatan yang akan melakukan suatu tindakan tertentu dengan mempertimbangkan berbagai informasi yang relevan.

Setiap situasi atau dilema etis berbeda cara pendekatannya, namun dalam situasi apapun perawat dapat menggunakan panduan berikut ini untuk pemrosesan dan pengambilan keputusan etis:

a. Menunjukkan maksud baik 
Penting bagi perawat dan semua tim yang terlibat mengikuti diskusi etik dengan anggapan bahwa semua tim menemukan apa yang baik bagi tidakan yang akan diberikan kepada klien. Diskusi harus dimulai dengan etikat baik dan kepercayaan pada semua anggota tim, jika tidak dimulai dengan saling percaya dan prinsip berbuat baik maka hasil yang diputuskan tidak akan memberikan kebaikan pada klien dan mencegah terjadinya kesalahan dan kejahatan pada klien dan keluarganya.

b. Mengidentifikasi semua orang penting

Sebelum pengambilan keputusan etis, perawat hendaknya mengingatkan bahwa semua orang/anggota tim ikut serta dalam proses pengambilan keputusan moral adalah penting. Tidak menilai seberapa besar porsi nilai yang diberikan oleh masing-masing anggota tim, prinsipnya bahwa keputusan yang diambil adalah keputusan bersama atau keputusan tim.

c. Mengumpulkan informasi yang relevan

Menggali atau mengumpulkan semua informasi sangatlah penting sebelum keputusan etis diambil. Informasi yang relevan meliputi data tentang pilihan klien, sistem keluarga, diagnosa dan prognosa medis, pertimbangan sosial dan dukungan lingkungan. Pengumpulan data merupakan langkah yang sangat penting dalam proses pertimbangan pengambilan keputusan etis. Perawat atau tim perawat tidak dapat mengambil keputusan yang baik jika berdasarkan data-data atau informasi yang lemah. Oleh karena itu, perawat harus mampu mengumpulkan informasi yang paling relevan sebagai dasar pengambilan keputusan etis bagi klein.

d. Mengidentifikasi prinsip etis yang penting

Keputusan etis harus didasari prinsip etis yang sesuai, walaupun prinsip etis yang umum dan universal tidak dapat menunjukka pada perawat apa yang harus ia lakukan dalam situasi kritis. Tetapi prinsip etis tersebut tetap harus dijadikan standar pegangan bagi perawat untuk mengambil keputusan etis, karena dapat membantu dalam menilai dalam

situasi dilema tersebut. Sehingga dapat mencari solusi untuk mengesampingkan atau menghilangkan hal yang dapat menghalangi norma dan nilai keputusan etis akan menjadi lebih baik.

e. Mengusulkan tindakan alternatif

Perawat sering kali sulit mengatasi masalah etis yang dihadapi, karena mereka hanya dapat melihat satu tindakan yang mungkin dapat diberikan kepada klien. Tanpa 
memberikan kebebasan untuk menentukan pilihan yang masuk akal yang dapat melindungi nilai kemanusiaan yang pada orang-orang yang terlibat.

f. Melakukan tindakan

Begitu keputusan etis telah diambil berdasarkan hasil diskusi tim yang dilakukan secara terbuka dengan melibatkan semua unsur yang terkait, maka perawat atau tim dapat mengimplementasikannya dalam bentuk tindakan keperawatan sesuai dengan standar asuhan keperawatan.

Pengambilan keputusan adalah sebuah hasil dari pemecahan masalah, jawaban dari suatu pertanyaan sebagai hukum situasi, dan merupakan pemilihan dari salah satu alternatif-alternatif yang ada, serta pengakhiran dari proses pemikiran tentang masalah atau problema yang dihadapi, adapun hasil dari pengambilan keputusan adalah keputusan(decision). Proses Keperawatan merupakan proses pemecahan masalah yang menekankan pada pengambilan keputusan tentang keterlibatan perawat sesuai yang dibutuhkan pasien. Proses keperawatan terdiri dari 5 tahapan yaitu : pengkajian, penentuan diagnosa keperawatan, intervensi keperawatan, implementasi dan evaluasi.

1. Pengumpulan data

Dalam pengumpulan data hal - hal yang harus diperhatikan antara lain : Mengetahui tujuan / maksud dari pengumpulan data, apa yang akan dilakukannya, manfaat yang didapat dari data tersebut, alat yang dibutuhkan untuk melakukan pengumpulan data, hal yang harus diperhatikan dalam wawancara, Teknik yang digunakan pada saat wawancara dan dalam fase apa yang sedang dijalani .Hal yang harus diperhatikan pada saat melakukan observasi/pengamatan, pemeriksaan fisik pasien. Mempelajari data yang ada sebelum memulai pengumpulan data, saat kapan data diperoleh akan menjadi patokan adanya masalah dan intervensinya. Informasi yang didapatkan sesuai dan dibutuhkan serta bagaimana intepretasinya, selain itu adanya masalah yang berasal informasi data dimana sudah teridentifikasi terutama data yang penting atau informasi menunjukkan masalah lain yang harus dipertimbangkan. Pada saat pengumpulan data hendaknya sudah mengumpulkan semua informasi yang diperlukan dan ada yang harus dilaporkan segera, selain itu mungkin memerlukan tambahan bantuan serta yang perlu di perhatikan pada pasien mempunyai faktor resiko, Komplikasi mana yang harus di awasi, faktor yang berhubungan dengan usia, bagaimana hubungan keluarga menghadapi situasi pasien, faktor budaya yang 
mempengaruhi, hasil akhir yang diharapkan pada pasien, tindakan pertama yang sesuai dari situasi pasien, rencana tindakan yang dapat disusun dengan tepat.

2. Perencanaan

Perencanaan merupakan suatu proses mempersiapkan serangkaian pengambilan keputusan untuk dilakukannya tindakan dalam mencapai tujuan organisasi, dengan dan tanpa menggunakan sumber-sumber yang ada (Sutarno NS, 2004). Perencanaan adalah proses pengambilan keputusan manajerial yang mencakup penelitian lingkungan, penggambaran sistem organisasi secara keseluruhan memperjelas visi, misi dan filosofi organisasi, memperkirakan sumber daya organisasi, mengidentifikasi dan memilih langkah-langkah tindakan, memperkirakan efektifitas tindakan dan menyiapkan karyawan untuk melaksanakannya (Gilles, 1994)

1. Meletakkan prioritas.

Perencanaan dibuat sesuai dengan prioritas diagnosis keperawatan yang telah ditetapkan dan selanjutnya Menentukan tujuan dan kriteria hasil, hasil yang diharapkan dari intervensi keperawatan dirumuskan dalam istilah tujuan / kriteria hasil yang harus spesifik, dapat diukur, dapat dicapai, yang sesuai dengan kenyataan dan ada periode waktu pencapaian, dan kriteria hasil sudah sesuai dengan standar/patokan normal

2. Mengidentifikasi intervensi yang interdependen

Dalam intervensi keperawatan kegiatan yang dilakukan untuk membantu memenuhi kebutuhan dasar klien didasari oleh kode etik dan standar praktek keperawatan profesional yang telah berlaku, klien dan keluarga disertakan dalam melakukan tindakan keperawatan. Intervensi keperawatan harus spesifik sesuai dengan pencapaian tujuan, didasarkan pada penyakit / masalah yang yang dialami klien. Informasi yang dimasukkan ke dalam rencana keperawatan dituliskan dengan cara yang ringkas, sistimatis sehingga memudahkan penggunaannya oleh tenaga keperawatan lain dan didalamnya memuat tindakan yang berbentuk kolaborasi dengan tim kesehatan lain sesuai dengan wewenang. Intervensi keperawatan hendaknya sudah diwujudkan melalui upaya promotif yaitu membantu klien yang kurang mampu untuk meningkatkan kemampuannya : upaya preventif,yaitu mencegah penyakit atau kecacatan, upaya rehabilitatif yaitu pemberian asuhan selama sakit dan upaya pemulihannya dan consolation of dring yaitu pendampingan bagi klien yang menghadapi kematian agar tenang dan bermartabat. Intervensi keperawatan bisa mencantumkan rencana keperawatan tambahan atau rencana 
keperawatan harus diulang kembali, serta perawat harus mengetahui bahwa rencana keperawatan dapat berubah jika prioritasmasalah bergeser, jika masalah teratasi dan jika didapatkan informasi tambahan tentang keadaan kesehatan pasien.

3. Membuat rasional tindakan dan mendokumentasikan.

Untuk membuat rasional setiap tindakan yang dilakukan diharapkan dengan benarserta pendokumentasian rencana keperawatan sudah sesuai dengan format yang ada yang terdiri dari diagnose keperawatan, tujuan dan kriteria hasil, intervensi keperawatan, dan rasional tindakan serta paraf diikuti nama jelas. Dalam pendokumentasian kalimat yang dihasilkan dalam rencana tindakan adalah kalimat perintah.

3. Implementasi

1. Mengkaji ulang

Sebelum melakukan implementasi, perawat melakukan pengkajian ulang untuk mengetahui apakah tindakan tersebut masih dibutuhkan oleh pasien atau tidak.

2. Menentukan kebutuhan bantuan.

Sebelum melakukan implementasi, perawat melakukan pengkajian apakah tindakan dapat dilaksanakan oleh perawat seorang diri atau membutuhkan bantuan

3. Melaksanakan tindakan keperawatan.

Saat mengimplentasikan asuhan keperawatan, perawat secara berkesinambungan mengkaji respons klien terhadap pelaksanaan tindakan yang telah dilakukan, dan semua rencana keperawatan diimplementasikan dengan menerapkan sikap-sikap berfikir kritis seperti integritas, kasih sayang, percaya diri dan keinginan untuk menerima serta memahami respons pasien. Saat intervensi keperawatan,implementasi rencana keperawatan dimodifikasi sesuai respon pasien.

4. Mendokumentasikan tindakan keperawatan

Setelah melaksanakan tindakan keperawatan, perawat mendokumentasikannya kedalam format catatan keperawatan dan menandatanginya. Pastikan pencatatan sudah dibuat secara ringkas, jelas dan obyektif serta memenuhi kriteria bahwa pencacatan yang dibuat menggambarkan intervensi keperawatan dan respons pasien terhadap intervensi tersebut, pencacatan yang dibuat semua data tambahan yang mencakup semua data yang relevan. Dalam melakukan pendokumentasian, catatan keperawatan menggunakan kalimat aktif,Perawat harus memperhatkan respon pasien, baik respons yang diungkapkan pasien maupun respon yang dilihat perawat. 
4. Evaluasi

Mengidentifikasi kriteria hasil sehingga perawat dapat mengukur keberhasilan pencapaian tujuan. Evaluasi bertujuan memperoleh informasi yang tepat sebagai bahan pertimbangan untuk mengambil keputusan tentang perencanaan program, keputusan tentang komponen input pada program, implementasi program yang mengarah kepada kegiatan dan keputusan tentang ouput menyangkut hasil dan dampak dari program kegiatan.

\section{Revisi Proses}

Setelah dilakukan pengambilan keputusan dan dilakukan evaluasi, kemudian dilakukan revisi proses yaitu perbaikan atas kekurangan pada pengambilan keputusan sebelumnya.

\section{Penutup}

Pengambilan keputusan sangat penting keberadaannya dalam asuhan maupun dalam manajemen keperawatan. Pengambilan keputusan merupakan suatu proses yang mencakup semua penilaian kegiatan yang diperlukan guna membuktikan dan memperlihatkan pilihan terbaik dalam menyelesaikan suatu masalah tertentu. setiap keputusan adalah akibat dari sebuah proses dinamis yang dipengaruhi oleh banyak kekuatan, pengambilan keputusan bukan merupakan prosedur yang tetap akan tetapi sebuah proses yang beruntun. pengambilan keputusan adalah proses yang melibatkan pendekatan sistemik yang harus diadaptasikan dengan lingkungan. Pengambilan keputusan keperawatan dilakukan pada semua tahap proses keperawatan. Sehingga seorang perawat harus mampu berpikir ktitis, berkomunikasi dengan baik sebagai suatu elemen penting dalam pengambilan keputusan klinis, sehingga terjadi pembelajaran berkelanjutan bagi pasien sehingga meningkatkan tingkat kemandirian pasien. Pengambilan keputusan adalah bagian yang kompleks, dipengaruhi oleh faktor individu, sosial, akses, dan sistem kesehatan.

\section{Daftar Pustaka}

Mugianti, S. 2016. Modul Bahan Ajar Cetak Keperawatan : Manajemen Kepemimpinan dalam Praktek Keperawatan. Jakarta : Pusdik SDM Kesehatan

Budiono. 2016. Modul Bahan Ajar Cetak Keperawatan : Konsep Dasar Keperawatan. Jakarta : Pusdik SDM Kesehatan 
Arifin, S., Rahman, F., Wulandari, A., Anhar, V.Y. 2016. BUKU AJAR Dasar-Dasar Manajemen Kesehatan. Banjarmasin : Pustaka Banua

Indriate. 2013. Berpikir Kritis Dalam Proses Keperawatan. Jurnal Keperawatan, 6 (2), 89-93

Deniati, K., Anugrahwati, R., Suminarti, T. 2018. PENGARUH BERFIKIR KRITIS TERHADAP KEMAMPUAN PERAWAT PELAKSANA DALAM MELAKUKAN ASUHAN KEPERAWATANDI RUMAH SAKIT HERMINA BEKASI TAHUN 2016. Jurnal Kesehatan Holistik, 12 (1), 21-25

Erianti, S., Machmud, R., Harmawati. 2019. Determinan Pengambilan Keputusan Klinik Keperawatan di RSUD Arifin Achmad Provinsi Riau. Jurnal Kesehatan Komunitas, 5 (3), 227 234

Purwati, E. I. I., Nuryadi, Herawati, Y. T. 2017. Pengambilan Keputusan dalam Pelaksanaan Rujukan Puskesmas sebagai Fasilitas Kesehatan Tingkat Pertama. e-Jurnal Pustaka Kesehatan, 5 (2), 231-238

Alfianur, Susanti, Padilah, R., Purnamasari, A. 2018. GAMBARAN PENGAMBILAN KEPUTUSAN KLINIS DALAM P4K (PROGRAM PERENCANAAN PERSALINAN DAN PENCEGAHAN KOMPLIKASI) DI DAERAH PESISIR PANTAI AMAL LAMA TARAKAN. Journal of Borneo Holistic Health, 1(2), 160-169

Pashar, I., Dwiantoro, L. 2020. Pengaruh Empowerment Terhadap Pengambilan Keputusan Perawat: Kajian Literature Review. Journal of Holistic Nursing Science, 7 (2), 124-132

Tim Pengajar FKM-UNSRAT. Modul Kuliah Sistem Informasi Kesehatan : Konsep Dasar dan Penerapan Sistem Informasi Kesehatan. Manado : Fakultas Kesehatan Masyarakat UNSRAT

Simamora, R. H. (2005). Hubungan Persepsi Perawat Pelaksana Terhadap Penerapan Fungsi Pengorganisasian Yang Dilakukan Oleh Kepala Ruangan Dengan Kinerjanya Diruang Rawat Inap RSUD Koja Jakarta Utara (Doctoral dissertation, Tesis FIK UI, Tidak dipublikasikan).

Simamora, R. H. (2019). Menjadi perawat yang: CIH'HUY. Surakarta: Kekata Publisher. 